
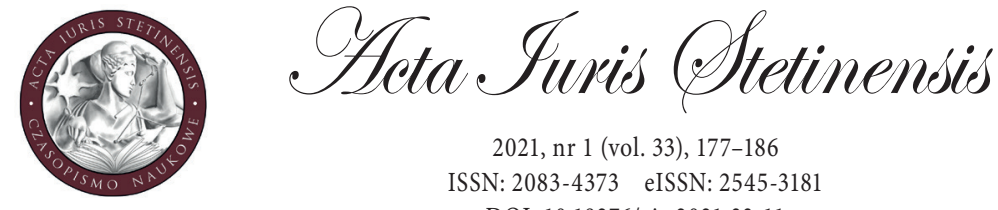

2021, nr 1 (vol. 33), 177-186 ISSN: 2083-4373 eISSN: 2545-3181
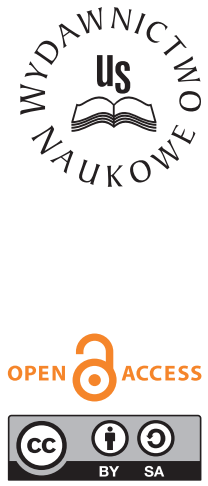

\title{
Wyrok Sądu Apelacyjnego w Szczecinie III Wydział Pracy i Ubezpieczeń Społecznych z dnia 9 czerwca 2020 r., III AUa 25/20
}

1. W postępowaniu toczącym się przed sądem pracy i ubezpieczeń społecznych, okoliczności mające wpływ na prawo do świadczeń lub ich wysokość mogą być udowadniane wszelkimi środkami dowodowymi przewidzianymi w kodeksie postępowania cywilnego - sąd nie jest ograniczony środkami dowodowymi przewidzianymi dla organu rentowego.

2. Orzekając o prawie do emerytury, które związane jest z wykonywaniem pracy w warunkach szczególnych, należy mieć na uwadze każdorazowo nie nazwę zajmowanego stanowiska, a rzeczywiście wykonywaną pracę i zakres powierzonych przez pracodawcę obowiązków.

Sąd Apelacyjny w Szczecinie III Wydział Pracy i Ubezpieczeń Społecznych w składzie następującym:

Przewodniczący: Sędzia Barbara Białecka (spr.)

Sędziowie: Jolanta Hawryszko, Urszula Iwanowska

po rozpoznaniu na posiedzeniu niejawnym w dniu 9 czerwca 2020 r. w S. sprawy I.Z. przeciwko Zakładowi Ubezpieczeń Społecznych Oddział w S. o prawo do emerytury pomostowej na skutek apelacji organu rentowego od wyroku Sądu Okręgowego w Szczecinie VI Wydziału Pracy i Ubezpieczeń Społecznych z dnia 3 grudnia 2019 r., sygn. akt VI U 1720/19

1. Oddala apelację. 
2. Zasądza od Zakładu Ubezpieczeń Społecznych Oddział w S. na rzecz ubezpieczonego I.Z. kwotę $240 \mathrm{zł}$ (dwieście czterdzieści złotych) tytułem zwrotu kosztów zastępstwa procesowego w postępowaniu apelacyjnym.

\section{Uzasadnienie}

Decyzją z dnia 10 czerwca 2019 roku organ rentowy - Zakład Ubezpieczeń Społecznych Oddział w S., po rozpatrzeniu wniosku ubezpieczonego - I.Z., odmówił ubezpieczonemu prawa do emerytury pomostowej.

Z powyższą decyzją nie zgodził się I. Z., który w odwołaniu wniósł o zmianę zaskarżonej decyzji i przyznanie mu prawa do emerytury pomostowej. Ubezpieczony zakwestionował stanowisko organu rentowego podnosząc, iż w okresie zatrudnienia w Spółdzielni Pracy (...) wykonywał pracę na stanowisku „rybak mechanik", a jego wynagrodzenie było uzależnione od wartości wyłowionej ryby.

W odpowiedzi na odwołanie Zakład Ubezpieczeń Społecznych wniósł o jego oddalenie $\mathrm{z}$ argumentacją wyrażoną $\mathrm{w}$ zaskarżonej decyzji.

Wyrokiem z dnia 3 grudnia 2019 r. Sąd Okręgowy w Szczecinie zmienił zaskarżoną decyzję organu rentowego $\mathrm{w}$ ten sposób, że przyznał ubezpieczonemu I.Z. prawo do emerytury pomostowej od 1 maja 2019 roku oraz orzekł o kosztach zastępstwa procesowego.

Sąd Okręgowy ustalił, że ubezpieczony I.Z. urodził się (...) - 55 lat ukończył $\mathrm{w}$ dniu (...). Ubezpieczony podlegał ubezpieczeniom społecznym łącznie przez 39 lat, 6 miesięcy i 5 dni.

W dniu 13 października 2016 roku ubezpieczony złożył w organie rentowym wniosek o emeryturę pomostową. Decyzją z dnia 17 listopada 2016 roku Zakład Ubezpieczeń Społecznych Oddział w S. odmówił ubezpieczonemu prawa do emerytury pomostowej. Ubezpieczony złożył odwołanie od ww. decyzji. Postanowieniem z dnia 23 maja 2017 roku Sąd Okręgowy w Szczecinie, wobec cofnięcia odwołania, umorzył postępowanie w sprawie.

W okresie od 19 listopada 1984 roku do 31 grudnia 1992 roku ubezpieczony był zatrudniony w Spółdzielni Pracy (...) w D. na stanowisku mechanika.

W okresie zatrudnienia ubezpieczony korzystał z urlopu bezpłatnego od 1 stycznia 1992 roku do 31 grudnia 1992 roku.

Pracując $\mathrm{w}$ (...) ubezpieczony stale i w pełnym wymiarze czasu pracy pracował na 17 metrowym kutrze jako jeden z członków załogi. Do obowiązków ubezpieczonego należała obsługa całej maszyny, sprawdzenie płynów chłodzących, oleju, płynów hydraulicznych, obsługa wind. Oprócz tego ubezpieczony pracował również przy obróbce ryb, przy wydawaniu i wyciąganiu siatki, sortowaniu ryb, chowaniu jej do ładowni. 
W okresie od 1 maja 2015 roku do 31 października 2016 roku oraz od 1 maja 2017 roku do 28 lutego 2019 roku I.Z. zatrudniony był w Rybołówstwo G. P. na stanowisku rybaka.

Ubezpieczony w okresie zatrudnienia wykonywał pracę wymienioną w załączniku nr 1 pkt 22 ustawy z dnia 19 grudnia 2008 roku o emeryturach pomostowych.

Ubezpieczony legitymuje się okresem ubezpieczenia wynoszącym 39 lat, 6 miesięcy i 5 dni, w tym przed organem rentowym wykazał 3 lata i 4 miesiące okresów pracy w szczególnych warunkach (od 1 maja 2015 roku do 31 października 2016 roku oraz od 1 maja 2017 roku do 28 lutego 2019 roku).

$\mathrm{Na}$ podstawie tak dokonanych ustaleń Sąd Okręgowy zważył, że odwołanie ubezpieczonego zasługiwało na uwzględnienie.

Jako podstawę prawną rozstrzygnięcia Sąd Okręgowy przyjął art. 4 ustawy z dnia 19 grudnia 2008 roku o emeryturach pomostowych (Dz. U z 2018 r., poz. 1924 ze zm.), zgodnie z którym prawo do emerytury pomostowej przysługuje pracownikowi, który spełnia łącznie następujące warunki:

1. Urodził się po dniu 31 grudnia 1948 roku.

2. Ma okres pracy w szczególnych warunkach lub o szczególnym charakterze wynoszący co najmniej 15 lat.

3. Osiągnął wiek wynoszący co najmniej 55 lat dla kobiet i co najmniej 60 lat dla mężczyzn.

4. Ma okres składkowy i nieskładkowy, ustalony na zasadach określonych w art. 5-9 i art. 11 ustawy o emeryturach i rentach z FUS, wynoszący co najmniej 20 lat dla kobiet i co najmniej 25 lat dla mężczyzn.

5. Przed dniem 1 stycznia $1999 \mathrm{r}$. wykonywał prace w szczególnych warunkach lub prace w szczególnym charakterze, w rozumieniu art. 3 ust. 1 i 3 ustawy lub art. $32 \mathrm{i}$ art. 33 ustawy o emeryturach i rentach z FUS.

6. Po dniu 31 grudnia $2008 \mathrm{r}$. wykonywał pracę w szczególnych warunkach lub o szczególnym charakterze, w rozumieniu art. 3 ust. 1 i 3.

7. Nastąpiło z nim rozwiązanie stosunku pracy.

Przy tym Sąd Okręgowy wskazał, że dla niektórych grup zawodowych ustalone są w art. 5-11 ustawy odrębne warunki przechodzenia na emeryturę pomostową w wieku niższym, niż 55 lat dla kobiet i 60 lat dla mężczyzn. Dotyczy to takich rodzajów prac, w przypadku których - ze względu większe obciążenia psychiczne i fizyczne towarzyszące ich wykonywaniu - ustawodawca dopuścił wcześniejsze przejście na emeryturę pomostową. Uprawnienia takie posiadają między innymi pracownicy wykonujący prace rybaków morskich.

Zgodnie $\mathrm{z}$ art. 8 ustawy o emeryturach pomostowych pracownik wykonujący prace w szczególnych warunkach wymienione m.in. w pkt 20, 22 i 32 załącznika 
nr 1 do ustawy, który spełnia warunki określone w art. 4 pkt 1, 4-7, nabywa prawo do emerytury pomostowej, jeżeli:

1. Osiągnął wiek wynoszący co najmniej 55 lat dla mężczyzn.

2. Ma okres pracy w szczególnych warunkach wymienionej w pkt 20, 22 i 32 załącznika nr 1 do ustawy, wynoszący co najmniej 10 lat.

$\mathrm{W}$ art. 3 ustawy wskazano, że prace $\mathrm{w}$ szczególnych warunkach to prace związane z czynnikami ryzyka, które $\mathrm{z}$ wiekiem mogą z dużym prawdopodobieństwem spowodować trwałe uszkodzenie zdrowia, wykonywane w szczególnych warunkach środowiska pracy, determinowanych siłami natury lub procesami technologicznymi, które mimo zastosowania środków profilaktyki technicznej, organizacyjnej i medycznej stawiają przed pracownikami wymagania przekraczające poziom ich możliwości, ograniczony w wyniku procesu starzenia się jeszcze przed osiągnięciem wieku emerytalnego, w stopniu utrudniającym ich pracę na dotychczasowym stanowisku; wykaz prac w szczególnych warunkach określa załącznik nr 1 do ustawy. Prace o szczególnym charakterze są to natomiast prace wymagające szczególnej odpowiedzialności oraz szczególnej sprawności psychofizycznej, których możliwość należytego wykonywania w sposób niezagrażający bezpieczeństwu publicznemu, w tym zdrowiu lub życiu innych osób, zmniejsza się przed osiągnięciem wieku emerytalnego na skutek pogorszenia sprawności psychofizycznej, związanego z procesem starzenia się; wykaz prac o szczególnym charakterze określa załącznik nr 2 do ustawy (art. 3 ust 3).

Za pracowników wykonujących prace w szczególnych warunkach lub o szczególnym charakterze uważa się pracowników wykonujących po dniu wejścia w życie ustawy prace, o których mowa w ust. 1 lub $3 \mathrm{w}$ pełnym wymiarze czasu pracy (art. 3 ust. 4 i 5). Za pracowników wykonujących prace w szczególnych warunkach uważa się także ubezpieczonych z tytułu działalności twórczej lub artystycznej tancerzy zawodowych, wykonujących po dniu wejścia w życie ustawy prace związane z bardzo ciężkim wysiłkiem fizycznym (art. 3 ust. 6) a za pracowników wykonujących prace $\mathrm{w}$ szczególnych warunkach lub o szczególnym charakterze uważa się również osoby wykonujące przed dniem wejścia w życie ustawy prace w szczególnych warunkach lub w szczególnym charakterze, w rozumieniu art. 3 ust. 1 i 3 ustawy lub art. 32 i art. 33 ustawy o emeryturach i rentach z FUS (art. 3 ust. 7).

Sąd Okręgowy wskazał, że w niniejszej sprawie poza sporem było, iż ubezpieczony posiada co najmniej 25-letni okres składkowy i nieskładkowy, ustalony na zasadach określonych $\mathrm{w}$ art. 5-9 i art. 11 ustawy o emeryturach i rentach z FUS, że ukończył 55 lat i nie pozostaje w zatrudnieniu. Przedmiotem sporu, w ocenie Sądu orzekającego, pozostawała możliwość uwzględnienia w stażu pracy ubezpieczonego w warunkach szczególnych, okresu zatrudnienia w Spółdzielni Pracy (...) w D. od 19 listopada 1984 roku do 31 grudnia 1991 roku. Organ rentowy odmówił 
ubezpieczonemu zaliczenia spornego okresu wykonywania pracy na stanowisku mechanika, wskazując, iż pracodawca nie potwierdził, że w ww. okresie wykonywał pracę wymienioną w pkt. 20, 22 i 23 załącznika nr 1 do ustawy o emeryturach pomostowych.

Powyższe stanowisko organu rentowego zobligowało Sąd Okręgowy do oceny, czy w analizowanym przypadku brak tego potwierdzenia stanowi przeszkodę do przyznania I.Z. prawa do emerytury pomostowej.

W ramach postępowania dowodowego Sąd I instancji dopuścił dowód z dokumentów zawartych w aktach emerytalnych ubezpieczonego. Dodatkowo czyniąc ustalania faktyczne, Sąd ten oparł się na zeznaniach świadków przesłuchanych w sprawie VI U 2226/16, tj. T.P., Z.L., P.B., A.G. i T.K. - byłych współpracowników ubezpieczonego z okresu zatrudnienia w Spółdzielni (...).

Autentyczność dokumentów nie była przez strony kwestionowana i nie budziła wątpliwości Sądu I instancji. Zostały one sporządzone w sposób zgodny z przepisami prawa, przez uprawnione do tego osoby, w ramach ich kompetencji, oraz w sposób rzetelny, stąd też Sąd Okręgowy ocenił je jako wiarygodne. Prymat wiarygodności przyznał Sąd orzekający także zeznaniom świadków oraz korespondującym z tymi zeznaniami zeznaniom ubezpieczonego. Oceniając zeznania ubezpieczonego, Sąd Okręgowy miał przy tym na względzie, że ubezpieczony jako osoba zainteresowana korzystnym dla siebie rozstrzygnięciem mógłby wprawdzie próbować zatajać przed Sądem okoliczności mogące wpłynąć niekorzystnie na ustalenia $\mathrm{w}$ zakresie wykonywania przez niego prac w warunkach szczególnych. Jednakże w swoich wyjaśnieniach nie pomijał żadnych okoliczności, zdając pełną relację ze wszystkich obowiązków powierzanych mu w kwestionowanych przez organ rentowy okresach. Oceniając zeznania świadków, Sąd orzekający miał z kolei na względzie, że przesłuchane osoby są osobami obcymi dla ubezpieczonego i nie mają żadnego interesu w tym by nieprawdziwie zeznawać na korzyść ubezpieczonego, narażając się jednocześnie na odpowiedzialność karną. Zeznania przesłuchanych świadków były przy tym spójne, konsekwentne i zbieżne z wyjaśnieniami ubezpieczonego, nie budząc jakichkolwiek wątpliwości Sądu Okręgowego co do ich wiarygodności. Świadkowie byli pracownikami zatrudnionymi w Spółdzielni (...) w tym samym czasie co ubezpieczony, a zatem mieli bezpośrednią wiedzę odnośnie do powierzonych ubezpieczonemu obowiązków.

Po przeprowadzeniu w sprawie postępowania dowodowego Sąd I instancji uznał, iż w dacie złożenia wniosku o emeryturę pomostową, wnioskodawca niewątpliwie spełnił wszystkie warunki do przyznania przedmiotowego świadczenia, określone $\mathrm{w}$ art. $4 \mathrm{w}$ zw. $\mathrm{z}$ art. 8 ustawy o emeryturach pomostowych. Ubezpieczony wykazał bowiem, że legitymuje się okresem pracy w szczególnych warunkach wymienionej w pkt 22 załącznika nr 1 do ustawy, wynoszącym co najmniej 10 lat. W ocenie Sądu 
z materiału dowodowego jednoznacznie bowiem wynika, że ubezpieczony w spornym okresie zatrudnienia wykonywał pracę rybaka morskiego, o której mowa w załączniku nr 1 poz. 22 do ustawy o emeryturach pomostowych.

W tym zakresie Sąd Okręgowy wziął pod uwagę, że z przedłożonych przez ubezpieczonego dokumentów oraz zeznań ubezpieczonego i świadków wynika, że w okresie zatrudnienia w Spółdzielni Pracy i (...) zajmował stanowisko mechanika. $\mathrm{Z}$ materiału dowodowego wynika przy tym, że ubezpieczony pracował wówczas na morzu, pływając jako członek załogi kutra rybackiego. Sąd I instancji zwrócił uwagę, że z zeznań świadków i ubezpieczonego wynikało, że I.Z. pływał na 17 metrowym kutrze jako jeden z członków załogi. Do obowiązków ubezpieczonego należała wówczas obsługa całej maszyny, sprawdzenie płynów chłodzących, oleju, płynów hydraulicznych, obsługa wind. Sąd Okręgowy zaznaczył, na co wskazywali wszyscy zeznający świadkowie, że prócz tego ubezpieczony pracował również przy obróbce ryb, przy wydawaniu i wyciąganiu siatki, sortowaniu ryb, chowaniu jej do ładowni. Zdaniem Sądu Okręgowego mając na uwadze zakres obowiązków ubezpieczonego na zajmowanym stanowisku mechanika, przyjąć należy, że niewątpliwie wykonywał wówczas pracę rybaka morskiego. Ubezpieczony, realizując obowiązki przypisane dla stanowiska mechanika, jednocześnie wykonywał bowiem pracę przy połowie i przetwarzaniu ryb.

Sąd Okręgowy podzielił pogląd Sądu Najwyższego wyrażony w wyroku z dnia 24 stycznia 2014 r. II UK 33/13, iż pojęcie „prace rybaków morskich”, użyte w pkt 22 załącznika nr 1 do ustawy z dnia 19 grudnia 2008 r. o emeryturach pomostowych (Dz.U. Nr 237, poz. 1656 ze zm.), do którego odwołuje się art. 8 tej ustawy, obejmuje nie tylko prace członków załogi zatrudnionych na stanowisku rybaka oraz starszego rybaka, ale również zajmujących stanowisko mechanika lub motorzysty. Artykuł 8 ustawy z 2008 r. o emeryturach pomostowych obejmuje swą dyspozycją wszystkie osoby, wykonujące prace rybaków morskich, wymienione zarówno w wykazie A, jak i B załącznika do rozporządzenia z dnia 7 lutego 1983 r. w sprawie wieku emerytalnego pracowników zatrudnionych w szczególnych warunkach lub w szczególnym charakterze (Dz. U. Nr 8, poz. 43). Nie można bowiem, bez wyraźnej podstawy prawnej, tożsamego pojęcia „prace rybaków morskich” traktować odmiennie: w sposób zawężający na potrzeby ustawy o emeryturach pomostowych oraz w sposób szeroki, z uwzględnieniem pracy członków załogi kutra rybackiego w służbie mechanicznej, na potrzeby ustawy z 1998 r. o emeryturach i rentach z Funduszu Ubezpieczeń Społecznych.

Mając na uwadze powyższe - w ocenie Sądu Okręgowego - należało uznać, iż I.Z. spełnił wszystkie przesłanki warunkujące nabycie prawa do emerytury pomostowej. 
W myśl przepisu art. 129 ust. 1 ustawy emerytalnej - świadczenia wypłaca się, poczynając od dnia powstania prawa do tych świadczeń, nie wcześniej jednak niż od miesiąca, w którym zgłoszono wniosek lub wydano decyzję z urzędu, z uwzględnieniem ust. 2.

$\mathrm{Z}$ wyrokiem nie zgodził się organ rentowy. Rozstrzygnięciu zarzucił:

1. Obrazę przepisów prawa materialnego, tj.:

- $\quad$ art. 49 w związku z art. 8 ustawy z dnia 19 grudnia 2008 r. o emeryturach pomostowych (Dz. U. z 2008 r. Nr 237, poz. 1656 z późn. zm.), poprzez uznanie, że ubezpieczony przez co najmniej 10 lat w okresie zatrudnienia od 19.11.1984 r. do 31.12.1992 r. w Spółdzielni Pracy (...) w D., wykonywał prace rybaka morskiego, tj. pracował na stanowisku wskazanym w poz. 22 załącznika $\mathrm{nr} 1$ do ustawy o emeryturach pomostowych i w konsekwencji przyznanie mu emerytury pomostowej.

2. Sprzeczność istotnych ustaleń Sądu z treścią zebranego materiału dowodowego w sprawie wskutek naruszenia przepisów postępowania, które miało wpływ na wynik sprawy, a mianowicie:

- $\quad$ art. 233 k.p.c. w związku z art. 227 k.p.c. poprzez przekroczenie granic swobodnej oceny dowodów, polegające na uznaniu, iż ubezpieczony wykonywał pracę rybaka morskiego, wbrew treści świadectwa pracy w szczególnych warunkach z dnia 6 stycznia 1993 r. oraz wbrew zeznaniom świadków, wskazujących na wykonywanie przez wnioskodawcę pracy na stanowisku mechanika.

Skarżący organ wniósł o zmianę zaskarżonego wyroku i oddalenie odwołania ewentualnie o uchylenie zaskarżonego wyroku i przekazanie sprawy do ponownego rozpoznania Sądowi I instancji, a nadto o zasądzenie od wnioskodawcy na rzecz pozwanego kosztów postępowania, w tym kosztów zastępstwa procesowego wg norm przepisanych.

W odpowiedzi na apelację ubezpieczony wniósł o jej oddalenie w całości oraz o zasądzenie na rzecz wnioskodawcy od pozwanego kosztów zastępstwa procesowego w postępowaniu apelacyjnym wg norm przepisanych.

Sąd Apelacyjny zważył, co następuje:

Apelacja jest nieuzasadniona.

Sąd Apelacyjny, dokonując własnej oceny przedstawionego pod osąd materiału procesowego, stwierdził, że Sąd Okręgowy w sposób prawidłowy przeprowadził postępowanie dowodowe, a poczynione ustalenia faktyczne nie są wadliwe i znajdują odzwierciedlenie w treści przedstawionych w sprawie dowodów. Sąd Odwoławczy ustalenia faktyczne Sądu Okręgowego czyni częścią uzasadnienia własnego wyroku, nie znajdując potrzeby ponownego ich szczegółowego przytaczania. 
W niniejszej sprawie Sąd Odwoławczy skorzystał z możliwości rozpoznania sprawy na posiedzeniu niejawnym, nie znajdując przesłanek do skierowania sprawy na rozprawę (art. 374 k.p.c.).

Do przesłanek przyznania prawa do emerytury pomostowej określonych w art. 8 ustawy pomostowej, mających zastosowanie w niniejszej sprawie, należy wykonywanie przez okres co najmniej 10 lat prac w szczególnych warunkach wymienionych w punkcie 20, 22 i 32 załącznika nr 1 do ustawy, spełnienie warunków z art. 4 pkt 1, 4-7 ustawy oraz ukończenie 55 lat życia w przypadku mężczyzny. Z kolei w punkcie 22 załącznika $\mathrm{nr} 1$ do ustawy pomostowej zostały wymienione prace rybaków morskich. Ustawa nie definiuje tego pojęcia, dlatego pomocniczo można odnieść się do znaczenia nadanego im w rozporządzeniu Rady Ministrów z 1983 r., które w swoim załączniku zawiera określenie: „prace rybaków morskich” i wymienia je w dwóch odrębnych pozycjach - w wykazie A, Dziale VIII (w Transporcie i łączności) pod pozycją 9 oraz w Wykazie B, Dziale IV (Prace różne) pod pozycją 4.

W przypadku prac rybaków morskich, dla ustalenia, jakiego rodzaju prace ustawodawca zaliczył do poszczególnych wykazów, konieczne jest posłużenie się resortowymi wykazami stanowisk, które jakkolwiek nie stanowią samodzielnej podstawy przyznania indywidualnych uprawnień, posiadają jednak charakter informacyjny, techniczno-porządkujący i uściślający, w szczególności wówczas, gdy w wykazie stanowiącym załącznik do rozporządzenia nie wymienia się określonych stanowisk, lecz operuje się pojęciem ogólnym. W zarządzeniu nr 24 z 1983 r. do wykazu B zostały zaliczone prace rybaków morskich w służbie pokładowej, a do wykazu A prace rybaków morskich w służbie mechanicznej, zgodnie z podziałem wynikającym z $₫ 58$ i $₫ 62$ ust. 1 i $₫ 64$ ust. 3 rozporządzenia Ministra Żeglugi z dnia 30 października 1971 r. w sprawie kwalifikacji zawodowych członków załóg polskich statków morskich (Dz.U. nr 33, poz. 299 ze zm.), w $\$ 54,58$ i 61 ust. 3 rozporządzenia Ministra - Kierownika Urzędu Gospodarki Morskiej z dnia 17 sierpnia 1983 r. w sprawie kwalifikacji zawodowych członków polskich statków morskich (Dz.U. nr 52, poz. 232 ze zm.), w $\$ 26,27,30$ i 31 rozporządzenia z dnia 23 maja 1992 r. Ministra Transportu i Gospodarki Morskiej w sprawie kwalifikacji zawodowych i składu załóg polskich statków morskich (Dz.U. nr 49, poz. 227 ze zm.) oraz $\$ 38$ i $\$ 49$ rozporządzenia Ministra Transportu i Gospodarki Morskiej z dnia 24 sierpnia 2000 r. w sprawie wyszkolenia i kwalifikacji zawodowych, pełnienia wacht oraz składu załóg statków morskich o polskiej przynależności (Dz.U. nr 105, poz. 1117).

W wywiedzionej apelacji organ rentowy podniósł, że w uchwale z dnia 17 września 2015 r. III UZP 7/15 Sąd Najwyższy wyraźnie wskazał, iż za prace rybaków morskich ujęte $\mathrm{w}$ pkt 22 załącznika $\mathrm{nr} 1$ należy uznać prace rybaków morskich w służbie pokładowej, a nie prace wykonywane na wszystkich stanowiskach 
zajmowanych przez pracowników wpisanych na listę członków załogi statku rybackiego. Natomiast stanowisko mechanika i motorzysty nie może być utożsamione ze stanowiskiem rybaka.

W niniejszym postępowaniu zatem wyjaśnić należało wątpliwości dotyczące charakteru wykonywanej przez ubezpieczonego w spornym okresie pracy. Sąd Odwoławczy bowiem w tym miejscu zauważa, że nie można utożsamiać pracy wykonywanej na dużych statkach rybackich i pracy wykonywanej na małych kutrach. Zakres wykonywanych prac na poszczególnych jednostkach pływających może się bowiem znacząco różnić. $\mathrm{W}$ postępowaniu toczącym się przed sądem pracy i ubezpieczeń społecznych, okoliczności mające wpływ na prawo do świadczeń lub ich wysokość mogą być udowadniane wszelkimi środkami dowodowymi przewidzianymi w kodeksie postępowania cywilnego - sąd nie jest ograniczony środkami dowodowymi przewidzianymi dla organu rentowego (tak: Sąd Najwyższy w wyroku z dnia 2 lutego 1996 r., II URN 3/95). Jednocześnie orzekając o prawie do emerytury, które związane jest $\mathrm{z}$ wykonywaniem pracy w warunkach szczególnych, należy mieć na uwadze każdorazowo nie nazwę zajmowanego stanowiska, a rzeczywiście wykonywaną pracę i zakres powierzonych przez pracodawcę obowiązków. Na okoliczność charakteru zatrudnienia ubezpieczonego w spornych okresach Sąd I instancji przeprowadził dowód z przesłuchania zawnioskowanych świadków, zeznań ubezpieczonego, jak również dokumentów znajdujących się w aktach organu rentowego.

W ocenie Sądu Odwoławczego zebrany w sprawie materiał dowodowy jednoznacznie wskazuje, że ubezpieczony w spornych okresach był członkiem załogi kutra rybackiego i wypływał w rejsy, podczas których wszyscy członkowie załogi w tym także ubezpieczony, wykonywali wszystkie prace związane z połowem ryb. Pełnomocnik organu rentowego na rozprawie przed Sądem I instancji nie kwestionował tego, że załoga kutra liczyła od 4 do 7 osób. Co prawda stanowisko pracy ubezpieczonego nie zostało określone jako rybak morski, jednakże dowody zgromadzone w sprawie pozwalały na uznanie, że I.Z., podobnie jak pozostali członkowie niewielkiej załogi, pracę taką wykonywał.

I.Z. jako członek załogi kutra rybackiego pełnił obowiązki mechanika, które według świadków sprowadzały się do chwilowego zejścia ubezpieczonego pod pokład, by sprawdzić olej i resztę sprzętu, ponadto wykonywał prace rybaka takie jak wydawanie siatki oraz jej wyciąganie, sortowanie ryb, chowanie ich do ładowni, wyładunek w porcie.

Myli się apelujący, twierdząc, że ustalenie to jest sprzeczne z treścią świadectwa pracy z dnia 6 stycznia 1993 roku. Wprawdzie rzeczywiście jako stanowisko pracy wpisano „mechanik”, jednak następnie wskazano, iż wynagrodzenie ubezpieczonego będzie zależało od wartości złowionej ryby, co bezsprzecznie oznacza, 
że ubezpieczony, realizując obowiązki mechanika, również wykonywał pracę przy połowie i przetwarzaniu ryb. Nadto dostrzec trzeba, że organ w sposób wybiórczy potraktował zgromadzony w sprawie materiał dowodowy. Uwzględniając bowiem całość dokumentacji pracowniczej, zauważyć należało, że w umowie o pracę z dnia 19.11.1984 r. wskazano na zatrudnienie I.Z. na stanowisku młodszego rybaka, takie też stanowisko występuje na listach płac. Niezależnie od powyższego wszyscy świadkowie spójnie zeznali, że ubezpieczony de facto realizował obowiązki rybaka na kutrze. Nie było żadnych podstaw, by zeznaniom tym odmówić wiarygodności.

Sąd Apelacyjny zatem uznał, że I.Z. posiada dłuższy staż zatrudnienia w charakterze rybaka morskiego $\mathrm{z}$ racji zatrudnienia w okresach wynikających $\mathrm{z}$ ustaleń sądu, tj. także w okresie od 19.11.1984 r. do 31.12.1992 r. (po odliczeniu urlopu bezpłatnego). Po zsumowaniu tego okresu z tym uznanym przez organ uznać należało, że ubezpieczony spełnia warunki niezbędne do przyznania mu emerytury pomostowej z tego względu, że udowodnił ponad 10 lat pracy wymienionej w pkt 22 załącznika nr 1do ustawy pomostowej.

Z tych powodów Sąd Apelacyjny na podstawie art. 385 k.p.c. apelację jako nieuzasadnioną oddalił - pkt 1.

O kosztach postępowania orzeczono na podstawie art. 98 i art. 99 k.p.c. oraz na podstawie $\$ 10$ ust.1 pkt 2 rozporządzenia Ministra Sprawiedliwości z 22 października 2015 r. w sprawie opłat za czynności adwokackie (Dz.U.2017.1797 j.t.) - pkt 2. 